\title{
COVID-19 Outbreak in Colombia: An Analysis of Its Impacts on Transport Systems
}

\author{
Julian Arellana $\mathbb{D D}^{1}{ }^{1}$ Luis Márquez, ${ }^{2}$ and Victor Cantillo ${ }^{1}$ \\ ${ }^{1}$ Universidad del Norte, Barranquilla, Colombia \\ ${ }^{2}$ Universidad Pedagógica y Tecnológica de Colombia, Tunja, Colombia \\ Correspondence should be addressed to Julian Arellana; jarellana@uninorte.edu.co
}

Received 9 April 2020; Revised 6 July 2020; Accepted 28 July 2020; Published 14 August 2020

Academic Editor: Stefano de Luca

Copyright $(92020$ Julian Arellana et al. This is an open access article distributed under the Creative Commons Attribution License, which permits unrestricted use, distribution, and reproduction in any medium, provided the original work is properly cited.

The global COVID-19 outbreak has demanded drastic actions and policies from the governments and local authorities to stem the spread of the virus. Most of the measures involve behavioural changes from citizens to reduce their social contact to a minimum. Thus, these actions influence individual activity patterns and transport systems in different ways. This paper studies the short-term impacts on the transport system caused by the different policies adopted by the Colombian government and local authorities to contain the COVID-19 spread. Using official and secondary data concerning the seven most populated cities in Colombia, we analyse the impacts on three components of the transport system: air transport, freight transport, and urban transport. Results show that national policies and local decisions have decreased the demand for motorised trips across the cities, diminishing congestion levels, reducing transit ridership, and creating a reduction in transport externalities. The country banned air transport for passengers and only allowed air cargo for medical and necessary supplies, which will have negative consequences for the economics of the airline industry. During the first three months of the COVID-19, freight was the most resilient transport component. However, freight trips diminished around 38\%, affecting mainly the supply chain of nonessential products. During the pandemic, governments need to provide subsidies to maintain the system supply to avoid crowdedness and promote active transport by allocating less-used street space to cyclists and pedestrians. In the short term, transportation service providers will face a financial crisis, deepened by the pandemic, which will require government assistance for their recovery.

\section{Introduction}

The rapid spread of COVID-19 worldwide has generated a public health crisis that started in December 2019. In a few months, the virus spread worldwide from Wuhan, its epicentre in China. The crisis has challenged the ability of the governments to take actions to protect their citizens and has tested cities' transport system preparedness. On 31 January 2020, after 7,817 confirmed cases [1], the WHO declared the disease a Public Health Emergency of International Concern and called governments and public health authorities to intervene and contain the expected number of new infections and deaths.

Following the WHO recommendation, some governments adopted drastic measures to stem the spread of the virus based on the Chinese experience and previous health crisis [2]. The experience from China suggested that it is possible to contain the virus if governments implement tried and tested public health outbreak responses $[3,4]$. Furthermore, $\mathrm{Li}$ et al. [5] suggest that during an epidemic, policymakers should prioritise measures to contain the spread of the disease instead of favouring economic activities. Therefore, most of the measures implemented worldwide involve promoting behavioural changes from citizens to reduce their social contact to a minimum and restricting their travel habits.

Two months after the Public Health Emergency declaration, several cities worldwide were in lockdown, and countries had declared emergencies and mobilised extra funding to tackle the COVID-19 threat. They were also suspending intracity public transport, closing entertainment venues, and banning public gatherings [6]. Nevertheless, the 
mandatory quarantine policy for entire cities has had side effects concerning urban economies, mental health, individual activity patterns, and transport systems.

Some authors already warn about the negative impacts of control measures against COVID-19 spread. Research has focused on evaluating economic and other health implications of the pandemic. COVID-19 is expected to cause negative global macroeconomic impacts [7], even for G7 and China [8]. A simulation study performed by Ruiz Estrada, Park, and Lee [9] predicts dramatic drops in tourism, international trade, and air transport in China and other countries. Also, it predicts an increase in electricity consumption due to extensive quarantines and a higher demand for health services. Regarding other health implications, Wang et al. [10] warn about possible physical health impacts of home confinement in children in the long term. Meanwhile, transport impacts caused by pandemic are less studied.

COVID-19 affected travellers' behaviour as measures to control the spread of the pandemic have been to restrict carrying out certain activities outside the home. However, the impact may differ by mode of transport. In Budapest, Bucsky [11] reported that the public transport has seen the greatest decline of trips by far, while cycling experienced the lowest decrease due to pandemic restrictions. Similar patterns were observed in the Netherlands, where the use of public transport was impacted the most with a decrease of over $90 \%$ of trips. Moreover, $88 \%$ of people currently prefer individual modes compared to public or shared modes of transport [12]. Similarly, the analysis conducted by Aloi et al. [13] in Santander (Spain) revealed an overall mobility decrease of $76 \%$, with public transport being the most impacted as their users dropped by up to $93 \%$.

As a consequence of social distancing, people will travel less, will try to avoid public transport, and might travel more by car. An individual's well-being and health status might be negatively affected as it might result in social isolation and limited physical activity. Active modes might play an important role not only in maintaining well-being levels but also in maintaining physical activity levels reducing the risk of increased obesityand mental health problems [14].

Our analysis will centre around the impacts of social distancing measures on demand and supply of three components of the transport system: air transport, freight transport, and urban transport in the seven most populated Colombian cities. We will address three research questions. First, considering that urban and populated areas in developing countries are quite vulnerable to public health crises and face enormous challenges in surveillance, response, and public communication [15], we want to understand what the impacts of the disease are on travel behaviour and transport systems at the urban level. Second, we seek to describe how airlines, mass transit systems, and freight transporters responded to this crisis. Finally, in line with Ivanov [16] who calls for the need to develop pandemic supply chain plans to identify elements of risk preparedness and recovery policies applied to transport networks in case of epidemic outbreaks, we will identify the hazards and threats to transport systems during the current and postpandemic eras.
This paper seeks to contribute to the understanding of the impacts on travel behaviour and on the transport system caused by the different actions and policies adopted by the Colombian government and transport authorities to contain the COVID-19 spread. The research also seeks to contribute to current knowledge on public health crisis impacts by creating evidence-based research on its geographical location. Most studies report the experience in China, where the virus began, other Asian countries, and Europe, but there is scarce research on the Global South, especially in Latin America, where the pandemic lagged two months in its arrival.

The organisation of the paper contains six sections. The second section discusses measures against the spread of COVID-19 adopted internationally. The third section presents the methodology of the study and describes the study area. The fourth section lists actions and policies adopted by the Colombian government and local authorities during the first three months of the virus outbreak. The fifth section presents the impacts on transport systems for the adoption of such measures. Finally, the sixth section concludes and draws some recommendations for transport systems derived from the study.

\section{Measures against the Spread of COVID-19}

One of the first measures adopted by most of the governments after the WHO declaration was associated with international travel bans and border control actions [17]. The principal cause for the unstoppable spread of COVID-19 is our hypermobile society [18]. Globalisation and our massive transport systems, especially aeroplanes and transoceanic cruises, easily expose individuals to human-to-human virus transmission and are highly responsible for the fast spread of contagious epidemic diseases globally [9]. In this sense, travellers play a crucial role in bringing new cases to other countries, even if they are asymptomatic individuals [19].

After travel restrictions, countries adopted some other sets of measures to contain COVID-19 spread. Isolation, quarantine, social distancing, and community containment were among these measures [20]. Statistical models to estimate the probability of COVID-19 spreading from Wuhan to other cities in China before the quarantine [21] supported the necessity of implementing such measures. Regarding their effectiveness, based on the spread of the epidemic in China, Lin et al. [20] reported that the combined action of social distancing and traffic control is useful in preventing the epidemic. Besides the positive effects, the authors warned that these measures do not work everywhere. Social distancing measures are not effective when applied in lowpopulated cities. Notwithstanding, traffic control is better suited for cities with higher GDP per capita and population size [20].

Considering the actions adopted by the different countries and their impact to contain the spread of COVID19, Sohrabi et al. [22] derived some public policy guidelines. In the study, the authors note that the international response to the current pandemic has been more efficient compared to the previous public health crisis. Also, the authors point out 
delays in decision making at different levels to adopt travel restrictions, quarantine measures, and emergency announcements. Finally, in line with Lin et al. [20], the authors identified that transparency of information and good communication strategies to avoid public misinformation improves protection awareness and enhances public confidence. In the same vein, Allam and Jhones [23] highlight the need for strengthening smart city communication systems to democratise information and achieve transparency amongst stakeholders for providing adequate cooperation in the case of disasters.

Countries should not dismiss socioeconomic factors and the presence of different vulnerable groups in the implementation of such policies to contain the effects of the pandemic. Qiu et al. [24] identified that several socioeconomic factors could mediate the local and cross-city transmissions of the novel coronavirus 2019 (COVID-19) in China. Meanwhile, Tsai and Wilson [25] attract the attention of policymakers to consider vulnerable groups that could live in environments that are conducive to a disease epidemic. They argue that people experiencing homelessness usually live in congregate living settings, without proper access to necessary hygiene supplies that could promote virus transmission.

\section{Case Study, Methods, and Data}

Colombia is used as a case study in this paper. This country is a presidential democratic republic and a state with a decentralised government at regional (departments) and local (municipalities) scale. The country is a social state, a unitary republic with partial autonomy of regional authorities. According to Colombia's constitution, when events that constitute a severe public calamity occur, the president, with the signature of all the ministers, can declare a state of emergency and has the authority to issue decrees with the force of law, intended solely to address the crisis and the emergency.

Colombia is a typical Latin American country, whose population is 50 million inhabitants living on a surface close to 1.14 million square kilometres. Around $80 \%$ of its population lives in urban areas [26]. The seven most populated metropolitan areas within the country concentrate $40 \%$ of the Colombian population and produce about $60 \%$ of the country's GDP [27]. These seven areas are Barranquilla, Bogotá, Bucaramanga, Cali, Cartagena, Medellín, and Pereira.

The public health crisis caused by COVID-19 affected the country's system of activities and, therefore, the supply and demand for transport in all dimensions. This paper relies on official and secondary data concerning three components of the transport system (i.e., air transport, freight transport, and urban transport) considering these seven urban areas within the country.

3.1. Air Transport. The country has a long tradition in commercial aviation. Avianca is the leading airline of the country. This airline is the second oldest in the world and was created in 1919. Air transport demand in Colombia is very dynamic. During the last decade, the demand for air transport has grown at an average rate of $7 \%$ yearly. The recent incursion of low-cost airlines caused a shock in the market and tariffs decreased. The Colombian network of airports mobilises about 25 million domestic passengers per year and 14 million international passengers [28].

For the analysis, we obtained scheduled and tracked flights in the airports of the seven urban areas from March to June from the Flightradar24 webpage [29]. Flightradar24 is a global flight tracking service that provides information about aeronautical operations around the world.

3.2. Freight Transport. Freight flows across the country reach 300 million tons/year. Trucks mobilise around $81 \%$ of the cargo, while $15 \%$ is moved by rail (mainly coal), and $4 \%$ by inland waterways. Air cargo moves less than 200,000 tons a year within the country [30]. The Colombian Ministry of Transport regulates passenger and freight transport at the national scale.

For the analysis, we obtained freight trips by trucks running in the whole country from March to mid-June from the Logistic Portal webpage powered by the Colombian Ministry of Transport [30]. The Logistic Portal webpage provides information about freight operations in different modalities at the country level. Furthermore, we gathered information about freight transported by air from the Civil Aviation Authority of Colombia between January and April of 2019 and 2020 in the seven cities [28].

3.3. Urban Transport. Public transport is the most used mode in the urban areas of Colombia. The mayor of each city oversees the public transport systems. BRT systems and regular buses mainly compose public transport systems in all cities, except Bogotá, Cali, and Medellín. Cali has the particularity of having a fleet of buses operated by only one company, which is not the case of the rest of the cities where different operators coexist. Medellín is the only city that has a metro train line integrated into the public transit system. Meanwhile, cable cars are part of the systems in Bogotá [31], Cali, and Medellín.

In Bogotá, for instance, the public transport modal share represents around $36 \%$ of the near 22 million daily trips, while $38 \%$ are walking or cycling trips. Individual motorised transport modes (e.g., car, motorcycle, and taxi) represent $19 \%$ of the total demand. Other modes cover the remaining trips [32]. In Medellín, public transit ridership represents $34 \%$ of about 6.1 million daily trips. Walking and cycling are $28 \%$. Meanwhile, car, motorcycle, and taxi are $31 \%$ of the total demand [33].

For the analysis, we used three indicators. The first indicator captures congestion changes in the seven cities daily from March to mid-June using data obtained following the methodology developed by the IDB and IDB invest in their Coronavirus Impact Dashboard [34]. The second indicator reports changes with respect to a baseline in public transport demand for all cities. Transport 
TABle 1: Chronology of measures adopted by the Government of Colombia against the spread of COVID-19.

\begin{tabular}{|c|c|}
\hline Day & Government responses \\
\hline $\begin{array}{l}3 / 06 / \\
2020\end{array}$ & The national government confirmed the first case of COVID-19 in Colombia \\
\hline $3 / 12 /$ & State of emergency declaration \\
\hline 2020 & Social distancing: no more than 500 people in one place \\
\hline $\begin{array}{l}3 / 17 / \\
2020\end{array}$ & Closure of land, sea, and river borders until May 30.Mandatory preventive isolation for people older than 70 until May 31 \\
\hline $\begin{array}{l}3 / 20 / \\
2020\end{array}$ & Quarantine drill in Bogotá and other cities and departments for four days \\
\hline $\begin{array}{l}3 / 23 / \\
2020\end{array}$ & Suspension of domestic and international flights \\
\hline $\begin{array}{l}3 / 25 / \\
2020\end{array}$ & $\begin{array}{l}\text { Mandatory quarantine throughout the country until April 13Mobility of health and essential services staff is allowed (primary } \\
\text { economic sector). }\end{array}$ \\
\hline $\begin{array}{l}3 / 26 / \\
2020\end{array}$ & Measures on the provision of public transport services during the state of emergency are issued. \\
\hline $\begin{array}{l}4 / 08 / \\
2020\end{array}$ & First extension of the mandatory quarantine throughout the country until April 27. \\
\hline $\begin{array}{l}4 / 15 / \\
2020\end{array}$ & Measures to mitigate the economic effects of the pandemic in the transport sector are issued. \\
\hline $\begin{array}{l}4 / 24 / \\
2020\end{array}$ & $\begin{array}{c}\text { Second extension of the mandatory quarantine throughout the country until May 11.Regional buses are allowed to offer urban } \\
\text { public transport services. }\end{array}$ \\
\hline $\begin{array}{l}4 / 26 / \\
2020\end{array}$ & Manufacturing, utilities, and construction sectors (secondary economic sector) are allowed to work from April 27. \\
\hline $\begin{array}{l}5 / 05 / \\
2020\end{array}$ & Third extension of the mandatory quarantine throughout the country until May 25. \\
\hline $\begin{array}{l}5 / 11 / \\
2020\end{array}$ & Tertiary economic sector is allowed to return to work from May 11 (i.e., retail, information technology, and furniture). \\
\hline $5 / 22 /$ & Fourth extension of the mandatory quarantine throughout the country until May 31 and state of emergency extension until \\
\hline 2020 & August 31. \\
\hline $\begin{array}{l}5 / 28 / \\
2020\end{array}$ & $\begin{array}{l}\text { Fifth extension of the mandatory quarantine throughout the country until June 30.Shopping centres and hairdressing services } \\
\text { (service sector) are allowed to open from June } 1 .\end{array}$ \\
\hline $\begin{array}{l}5 / 30 / \\
2020\end{array}$ & Taxis can operate from June 1. \\
\hline
\end{tabular}

operators from each city reported aggregated information on passengers transported every day in the March to June period. The third indicator captures changes in activity and travel behaviour based on the COVID-19 Community Mobility Report as of June 12, 2020 [35]. We extracted the data to compare how visits and length of stay at different places change compared to a baseline. According to the report, the baseline was the median value for the corresponding day of the week, during five weeks (i.e., Jan 3-Feb $6,2020)$. We obtained the data over 16 weeks, from February 21 to June 12, 2020, and used the six categories defined by Google to analyse mobility trends, social distancing, and access to essential services. These categories are retail and recreation, grocery and pharmacy, parks, transit stations, workplaces, and residential. Because of user settings, connectivity, and Google's privacy thresholds, the data may or may not represent the exact behaviour of a wider population.

We completed all the analyses by interviewing stakeholders of the different components of the transport system. In the air transport sector, we interviewed airport managers and airline employees. From freight transport analysis, we interviewed officials of the Colombian Ministry of Transport and managers of freight forwarder companies. Finally, to analyse the urban transport impacts, we interviewed public transit operators, managers of intracity transport companies, and academics working in the analysed cities.

\section{Responses from the Government of Colombia (GoC) to COVID-19}

The GoC confirmed the first case of COVID-19 on March 6, 2020. As the virus continues to spread in Colombia, national, state, and local governments have been progressively taking measures to prevent transmission of the virus. Initial steps and recommendations from assorted government authorities created some confusion about what people should do to protect themselves and prevent transmission of COVID-19. The first actions were taken at the local level, particularly by the mayors of the main cities during March 9-11, oriented to keep social distancing as a measure to contain the spread of the virus. Conflicts emerged between local and national authorities.

However, on March 12, the President declared the state of emergency, which allowed leaders to unify the measures taken. As in most countries, in Colombia, general measures adopted have been social distancing, quarantine, and isolation. Most educational institutions (schools and colleges) closed by March 16. Table 1 summarises the primary responses of the GoC. Although the mandatory quarantine 
decreed by the GoC was initially defined until April 13, the evolution of the confirmed cases in the country justified its extension five times until June 30. Throughout this period, the $\mathrm{GoC}$ has allowed the gradual reactivation of economic sectors to avoid a greater impact on the national economy. The reactivation of these sectors has implied the adoption of biosafety protocols, the preservation of social distancing measures, and control by local authorities.

As of June 16,57,046 cases were confirmed, of which $1.5 \%$ were identified in people who had come from abroad (Figure 1(a)). Around 16.8\% were related to people who had contact with a confirmed case of COVID-19, and $81.6 \%$, in which a relationship with any transmission chain had not yet been clearly identified. This last percentage of cases, without a clear epidemiological link, suggests that COVID-19 could be circulating freely among the Colombian community.

Although there were people affected in all age ranges, the majority of cases were concentrated in people younger than 50 years and $58 \%$ corresponded to people younger than 40 years. Concerning deceased patients, $70 \%$ corresponded to people above the age of 60 , which is in line with the global trend in which the majority of victims are the oldest people. Even though the GoC implemented a mandatory preventive isolation measure for people older than 70 when 75 cases had been confirmed in the country, almost half of the deaths $(46 \%)$ correspond to this age group.

Regarding the geographical distribution in the national territory, all the 33 departments had confirmed cases of COVID-19, and Bogotá, being the capital, had the highest number of cases $(17,392)$. The closure of land and river borders appears to have contributed to containing the spread of the virus in border departments. The border departments (10 out of 33) concentrate less than $10 \%$ of all confirmed cases in the country (Figure 1(b)). However, on one hand, the fourth least-populated department in the country, the Amazonas where most of its population is indigenous, has the highest number of confirmed cases per 100,000 inhabitants $(3,298)$. On the other hand, the most populated departments in the northern coast of Colombia, where Barranquilla and Cartagena are located, have the highest number of cases per 100,000 people (522 and 291, respectively), being higher than the index for Bogotá (242 confirmed cases per 100,000 inhabitants).

All the measures taken by the GoC from the first confirmed case of COVID-19 infection, of course, had an economic impact in the population. It is well known that changes in the socioeconomic and activity systems will, in turn, call forth changes in supply chains and transport systems. The measures of social distancing, quarantine, lockdown, and isolation aimed to flatten the curve of the infection and produce changes in the demand for transport services and in supply chains that require corrective measures. For this reason, measures on the provision of public transport services were taken by the GoC.

Based on the state of emergency declaration, the rapid growth of COVID-19 in the world, and the increasing number of cases reported on March 24, there are $378 \mathrm{cu}-$ mulative confirmed cases, distributed in the capital district and in 19 of the 32 departments; the GoC issued Executive
Decree No. 482 of 26 March 2020 to take measures on the provision of public transport services in the state of economic, social, and ecological emergencies. With this decree, in order to advise and make decisions to guarantee the provision of public transportation services, the government created the Logistics and Transport Centre (LTC), comprised of high-level officials. The decree adopted two sets of measures.

The first set of measures derived from mobility restrictions and mandatory preventive isolation. These measures aim to adjust the supply of transport to the new demand conditions, derived from quarantine and preventive isolation measures, and guarantee the continuity of the supply chain, in healthy conditions, reducing some transport costs for the provision of goods and services. In this set of measures, we have to

(i) Reduce the supply of public transport services up to $50 \%$

(ii) Authorise the taxi service, only by telephone or through technological platforms

(iii) Ensure the freight transport services in the national territory for essential supplies

(iv) Suspend the time-limit for carrying out the technical-mechanical and polluting emissions review of all motor vehicles

(v) Provide "safe points" on national roads to examine drivers of passenger and cargo vehicles

(vi) Suspend toll collection for freight vehicles transiting the national territory

The second set of measures derived from the declaration of emergency and, on the other hand, is intended to provide economic relief for aeronautical industry and transport infrastructure concessionaires in the country. Below are the measures adopted to mitigate the income losses of airline operators:

(i) Streamline the return of balances in favour of airlines by the tax authority

(ii) Suspend the payment of charges from airport concessionaires

(iii) Suspend the maximum supplementary work cap for air traffic controllers, firefighters, and aeronautical technicians

(iv) In case of withdrawal requests, airlines may make reimbursements represented in services provided by themselves

(v) The Colombian aeronautical authority may modify the requirement of guarantees of compliance to aeronautical companies

(vi) The aeronautical authority may sign payment agreements with air transport companies

(vii) Suspend new charges related to airport infrastructure

(viii) Transitory suspension of leasing fees collection 


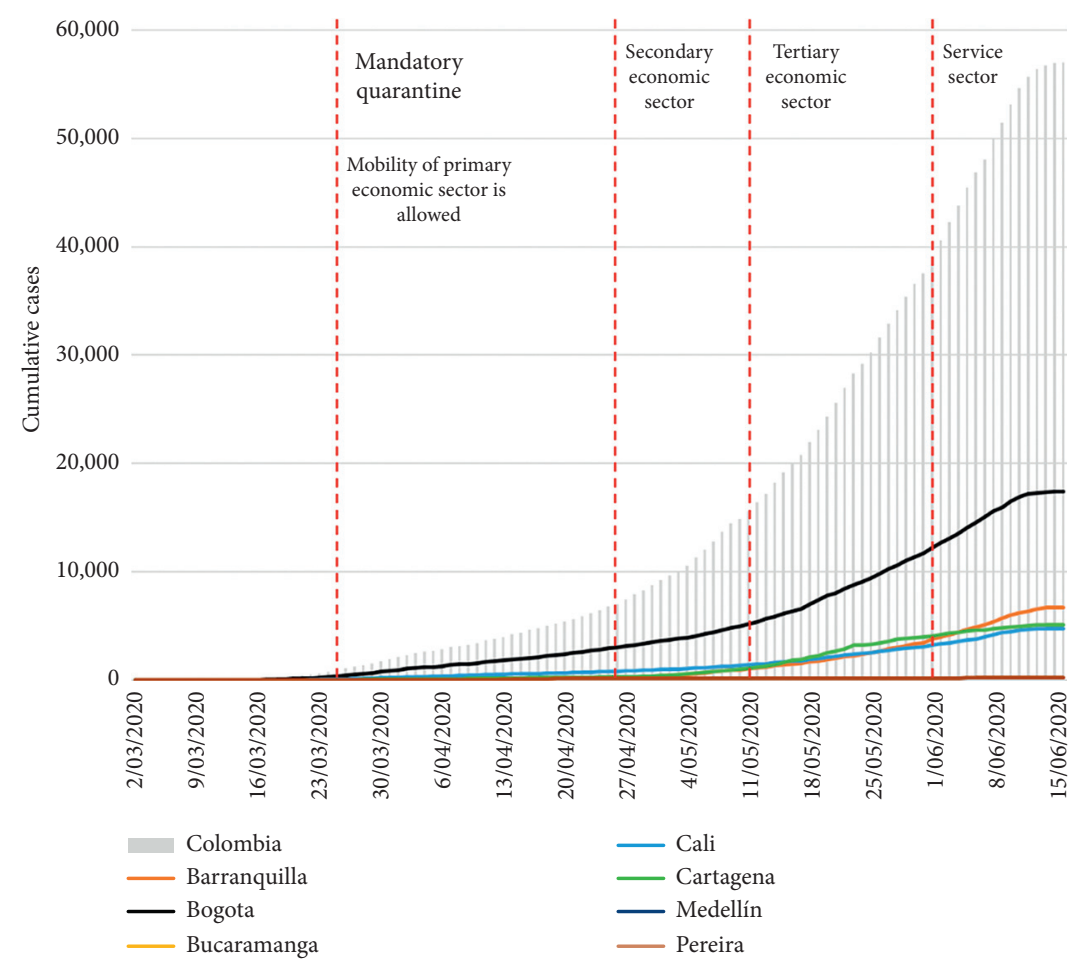

(a)

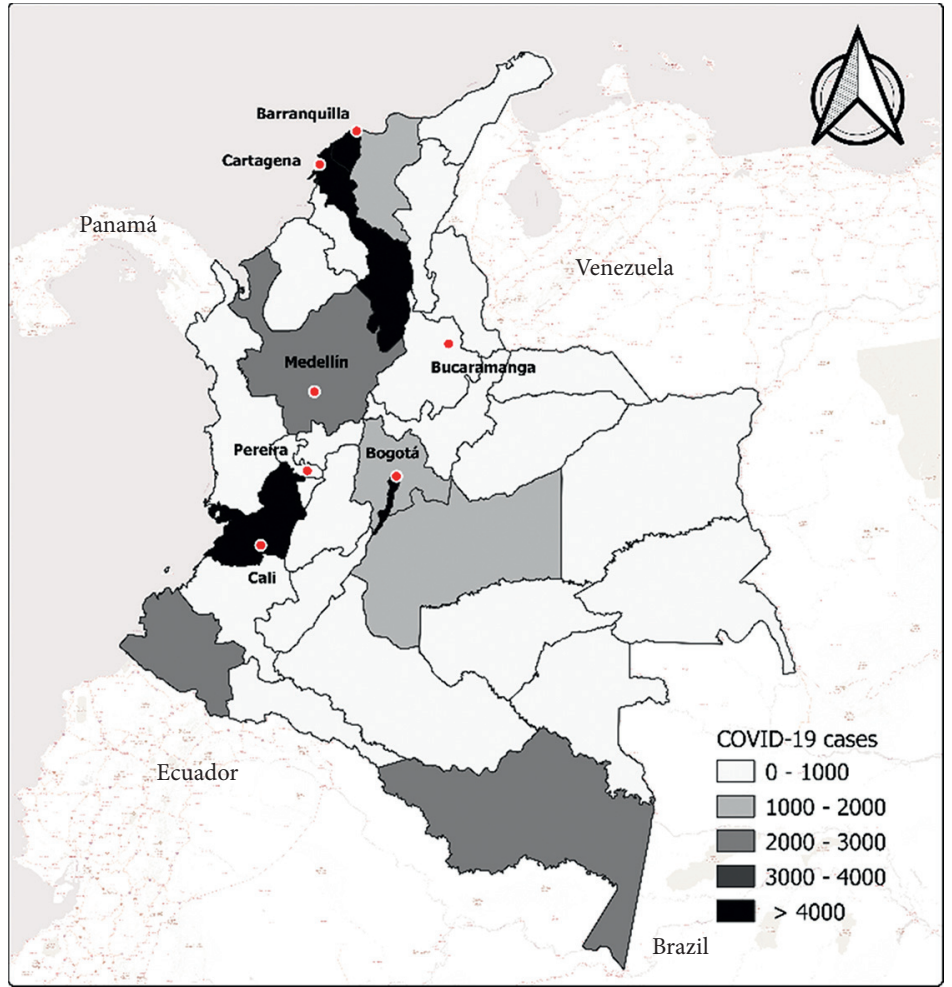

(b)

Figure 1: Cumulative cases and geographical distribution of confirmed COVID-19 cases in Colombia during the March to June 2020 period. (a) Cumulative confirmed cases in Colombia up to June 16. (b) Geographical distribution of confirmed cases in Colombia up to June 16. 
(ix) Transitory suspension of environmental restrictions on airport operating hours

Additionally, in line with the above measures, the GoC issued the following:

(i) Although as a rule they must be kept in operation, the LTC may order the suspension of any transport infrastructure

(ii) Authorise to continue the construction of transport infrastructure, complying with biosafety guidelines

(iii) Extend time up to $20 \%$ of the term initially agreed upon in the concession contracts

(iv) Authorise public entities to suspend building contracts of transport infrastructure

(v) Authorise to extend the terms of port concessions

(vi) Authorise private ports to attend transport operations to supply essentials goods, regardless of the type of cargo authorised to operate

Considering the number of confirmed cases by April 15, 2020 (i.e., 4,367), the GoC ruled that public transport vehicles must operate at a maximum of $35 \%$ of their capacity. The measure was justified as a strategy to maintain social distance, although it is not supported on rigorous technical analysis. However, to mitigate the economic impacts of the pandemic in the transport sector, the GoC approved a line of credit for public transport operators supported by approximately USD 1.3 million seed fund and the national guarantee fund. Also, the GoC offered additional tax exemptions for air and urban passenger transport. Meanwhile, direct subsidies for the operation of public transport systems or recovery funds have not yet been allocated by the national government.

Finally, on April 24, the GoC allowed regional buses to offer urban public transport services in order to comply with the $35 \%$ capacity constraint and satisfy new demand during the mandatory quarantine due to the restart of secondary economic sector activities by April 27. Recently, on June 1, the $\mathrm{GoC}$ conceded the operation of taxi services to supply the transport demand of primary, secondary, tertiary, and service sector employees who were exempt of the mandatory quarantine by the date.

\section{Impacts on Transport Systems}

This section reports the impacts on travel patterns and the different components of the transport system caused by the evolution of the COVID-19 and the measures adopted to contain it.

5.1. Air Transport. Figure 2 displays the ratio of scheduled vs tracked flights in the airports of the seven urban areas in Colombia during March 2020. Even though a continuous descendent trend of aeronautical operations is observed after the measures of preventive isolation for international passengers and the declaration of the state of emergency for the country on March 11, the drop in the number of flights was more evident from March 16. The entry restriction for nonnationals and nonresidents in Colombia increased the slope of all curves in Figure 2. The former measure followed by the closure of land, sea, and river borders of the country on March 17 profoundly affected air transport operations. These measures caused a decrease between $40 \%$ and $60 \%$ of the tracked flights during the period when only domestic flights were allowed.

However, the mandatory quarantine caused the highest decline in the number of commercial flights (Figure 2). It is important to note that the suspension of domestic and international flights on March 23 preceded the mandatory quarantine measure. The percentage of flights after March 25 corresponds only to air charters and cargo operations, mainly devoted to transport medical and necessary supplies.

All the cities show a similar drop pattern regarding air operations. However, Bucaramanga seems to be the most impacted airport in the early period after the state of emergency declaration. On the contrary, Barranquilla was the busiest airport after the start of the mandatory quarantine period. By the end of May and mid-June, the picture looks similar. Bogotá's airport was the busiest but only attending $2.3 \%$ to $2.7 \%$ of their regular flights. Medellín reported an average of two tracked flights per day $(1.6 \%$ of regular demand), while Barranquilla, Cartagena, and Cali registered between one and two tracked flights on average per week. Bucaramanga and Pereira did not report regular flight activities during the period.

According to Iacus et al. [36], the impact of aviation industry losses in the first quarter of 2020 could have decreased world GDP by $0.02 \%$ to $0.12 \%$, and at the end of 2020 , the loss could be as high as $1.41-1.67 \%$, while job losses may reach 25-30 million around the world. In Colombia, the situation is not different. The drastic and sudden closure of commercial flights will profoundly affect the economics of the airline industry in the country. For example, before the emergency declaration, Avianca Holdings reported a net loss of US $\$ 894$ million during 2019. The above loss was due to an increase in operating costs and a decline in sales compared to the previous year. The critical economic situation of the airline will inevitably worsen due to the closure of air operations, initially defined until May 30 . Avianca employees are experiencing the first consequences of the economic crisis in the sector. The company asked them to apply for an unpaid license period.

5.2. Freight Transport. Figure 3 shows the number of freight trips by trucks running in the whole country from March to June 2020. The drop on weekends is explained because trucks are restricted to circulate in highways on Sundays. The first three weeks of March present a similar pattern of freight trips, which suggests that measures adopted before the mandatory quarantine did not significantly affect freight transport. The provision of "safe points" to provide some care for drivers, the disinfection of cargo vehicles using highpressure washers, and the suspension of toll collection for freight vehicles in national roads helped to maintain the similar numbers of freight trips during the first three weeks. 


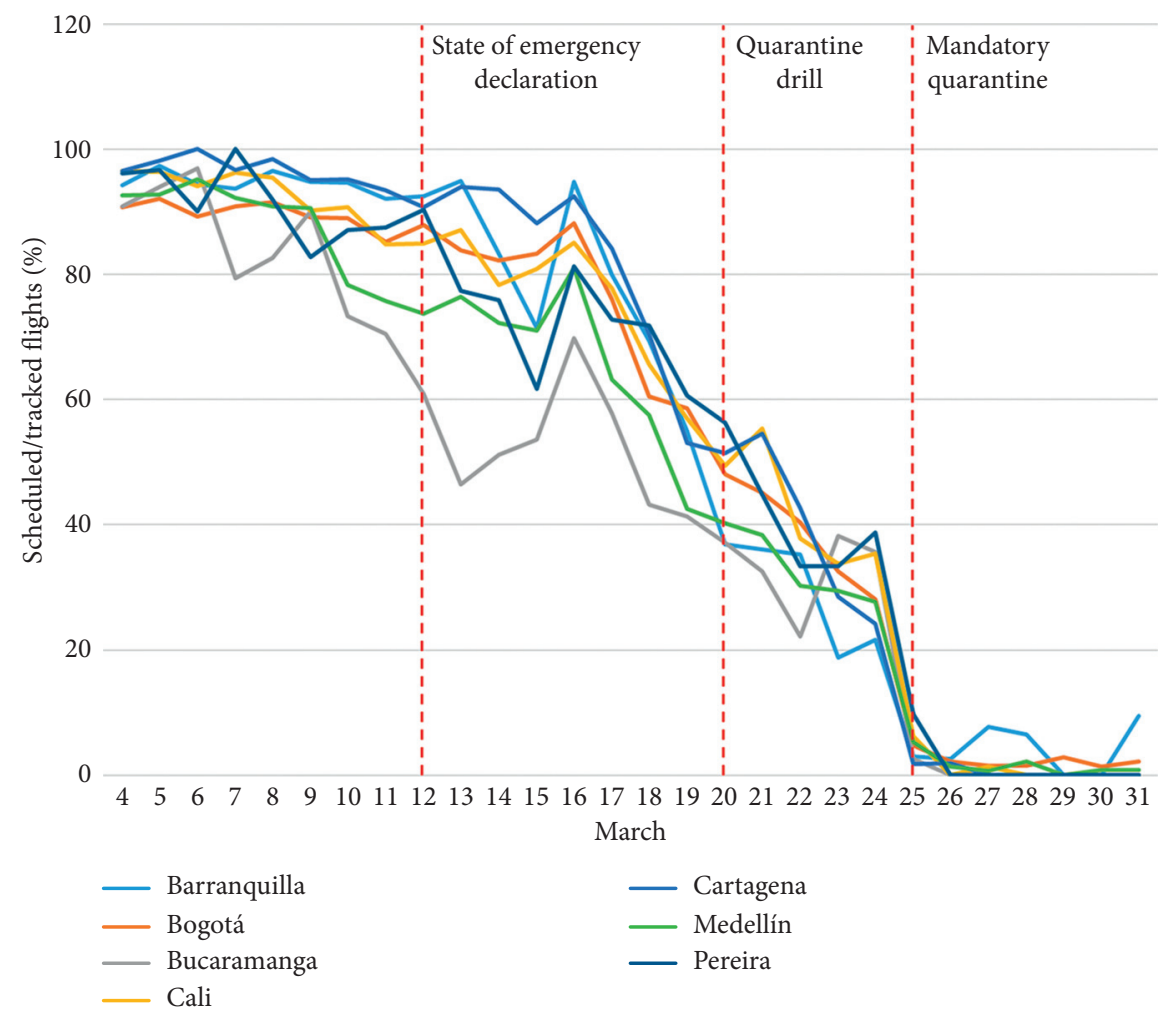

Figure 2: Percentage of completed flights in seven Colombian airports during March 2020.

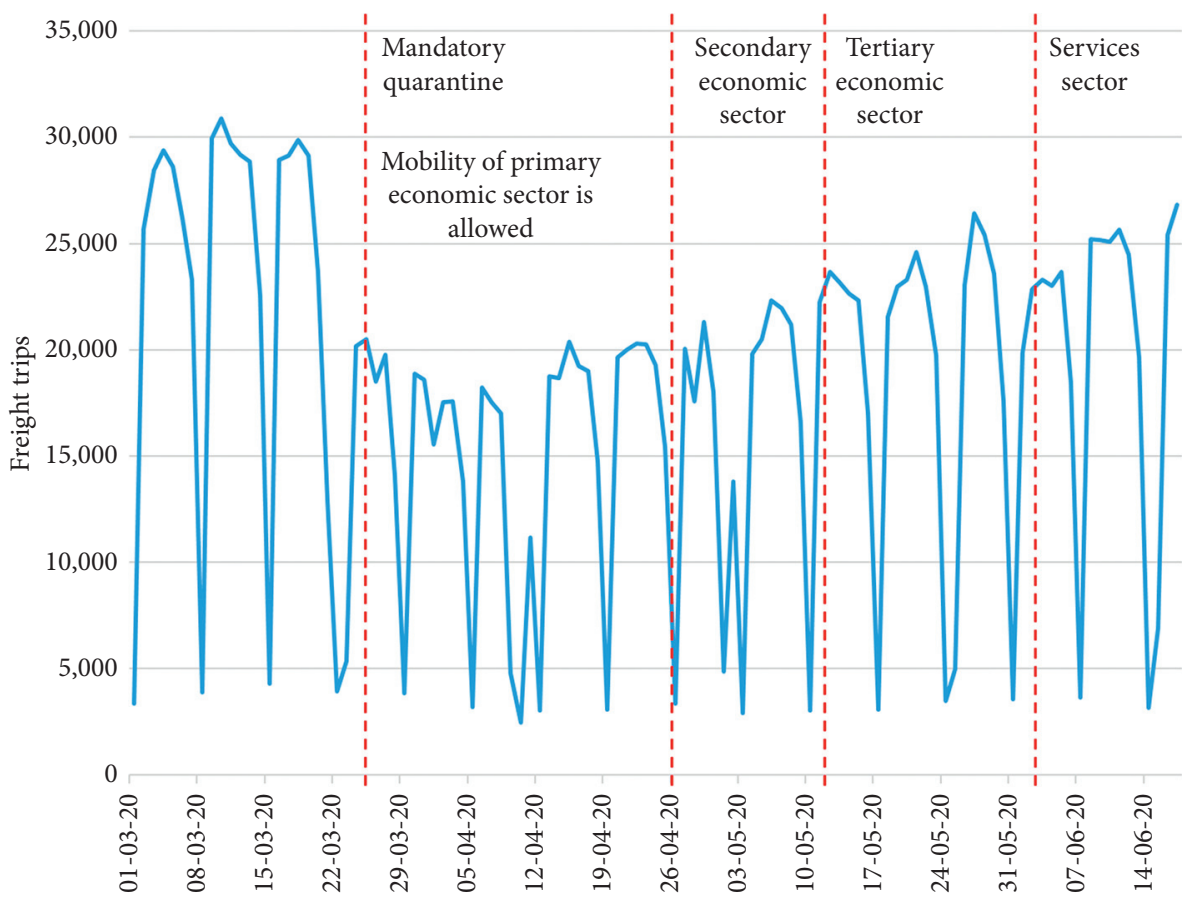

FIgURE 3: Freight trips in Colombia from March to June 2020.

However, there is an evident decline in cargo trips after March 25. The freight trips diminished around 38\% on average during the mandatory quarantine, considering the first three weeks period. Although the measures to promote freight transport were maintained during the quarantine, we hypothesise that the transport of nonessential products almost stopped. The reason for the above mainly being because some factories and companies closed due to the quarantine.

As different sectors of the economy were exempted from mandatory quarantine (i.e., from April 26) and returned to 
activities, freight trips within the country showed an increasing trend. However, the levels that were before the measures were decreed by the $\mathrm{GoC}$ have not yet been reached.

We also compared freight volumes transported by air reported by the Civil Aviation Authority of Colombia between January and April of 2019 and 2020 in the seven cities (Figure 4). Similar to the tendency of freight trips by road, freight volumes transported by air diminished during the pandemic (i.e., March and April 2020) in comparison to the volumes observed in the same months in 2019. Overall, the amount of air cargo decreased in all cities. Interestingly, Bucaramanga, Barranquilla, and Pereira reported minimal movement of air cargo during March, while Bogotá, Medellín, Cali, and Cartagena presented reductions between $40 \%$ and $70 \%$ compared to the same month of the previous year.

5.3. Urban Transport. Impacts on mobility at the urban level are the product of changes in activity and travel patterns due to the measures adopted by the authorities and citizens' fear of being infected. Figure 5 presents the trends in activity times based on the COVID-19 Community Mobility Report developed by Google.

Social distancing measures adopted by the Colombian government after the state of emergency declaration and the decision to close schools and cultural spaces by March 16 profoundly diminished the time devoted to activities outside the home. At the same time, the increase in residential activities is notable as they grew about $30 \%$.

It is interesting to note how people behaved just before the start of the mandatory quarantine period. Generally, individuals spent more time on all activities. However, visits to supermarkets and pharmacies grew much more than the trips to carry out other activities. On the day prior to the start of the quarantine, there were long queues in supermarkets, perhaps because people went to stock up on food, medicine, and other essential supplies.

After the mandatory quarantine was implemented, the mobility to shop retail, for recreation activities, and to visit parks diminished about $80 \%$ compared to the baseline. Meanwhile, trips to workplaces and shopping at groceries and pharmacies show a reduction of around $60 \%$. The above favoured the residential time, which increased to the highest $40 \%$.

Given the reduction of out of home activities after the state of emergency declaration, the congestion levels in the city also diminished. Figure 6 shows the changes in congestion levels, considering the seven cities in this study. The changes in congestion levels began to be evident in all cities after the state of emergency declaration, which coincides with the adoption of social distancing measures. These changes were more notable in Barranquilla, Cartagena, and Bucaramanga than in Bogotá and Medellín, where the congestion levels were around $60 \%$ of a typical day.

The dramatic reductions in congestion levels for all cities appeared after Friday, March 20. Bogotá and Medellín's mayors decided to run a quarantine drill for four days. The other cities just followed their reduction trend in congestion levels. During the drill, Medellín reported congestion reductions of around $77 \%$, which caused a $34 \%$ average increase for vehicle speeds [37].

Congestion levels for all cities, after the first month of the mandatory quarantine adoption, represent $10 \%$ at most of what happens on a typical day. Similar to freight transport situation, congestion levels increased quickly as different sectors of the economy were exempted from mandatory quarantine (i.e., from April 26) and returned to activities (Figure 6). Congestion level increases in all cities are more noticeable after the tertiary and service economic sectors restarted their activities. Although, in general, all cities increased their congestion levels, the changes were more pronounced in cities such as Bogotá, Medellín, and Cali. These cities exhibited congestion levels between $60 \%$ and $80 \%$ compared to a typical day. Motorisation rates in these cities are the highest across the country. Also, all three cities have different transportation demand management (TDM) strategies during typical days [38-40]. However, local authorities in these cities decided to suspend the applicability of the TDM measures during the pandemic. Furthermore, local authorities of cities such as Barranquilla and Cartagena because of their high number of confirmed cases per population decided to issue stricter mobility constraints to their inhabitants. Barranquilla and Cartagena only allow trips to essential errands (e.g., shopping, banking, and health) once a week, which differs from the other cities where inhabitants can go out at least two times a week.

Finally, we found a similar trend for public transport demand across days compared to the one observed to describe the change in congestion levels in the cities. Interestingly, congestion reductions were higher than demand reductions in public transport. Figure 7 shows that public transport systems gradually lost demand over the days after the declaration of the state of emergency. However, the demand drop was much more noticeable after March 20.

The case of Cartagena deserves attention because, due to local measures and the adoption of the highest supply reduction compared to all cities, it has maintained low public transport demand levels throughout the city. The low demand can be explained by the fact that tourism and commerce activities are closed, and they are among the largest sources of employment in the city. In summary, the demand reduction during the mandatory quarantine period in most of the public transport systems lays between $90 \%$ and $80 \%$, Cartagena being the city that experienced the highest demand loss during this period (96\%).

Achieving lower demand reductions in public transit systems than in congestion levels suggest that trip reductions in public transport modes are less than those for private transport modes. If our former hypothesis is correct, then it should be noted that the quarantine period could have a differential impact on transport users. In Colombia, public transport users mainly correspond to lower-income people compared to private transport users. Possibly, work activities for those lower-income individuals did not stop during quarantine, while higher-income individuals are more prone to teleworking. Moreover, informality in the country is about $46 \%$ [27], with most 


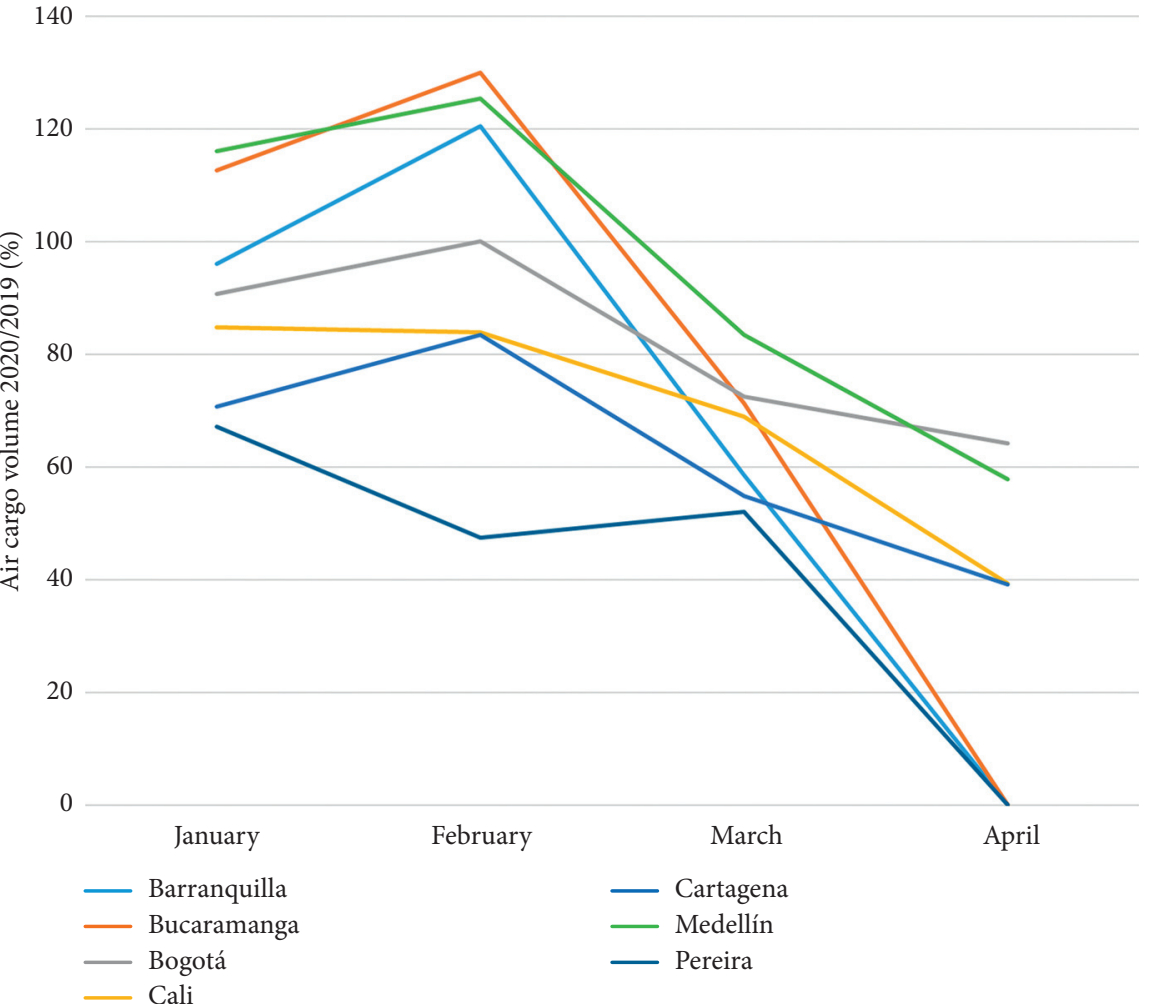

FIgure 4: Comparison of air cargo volumes in Colombia considering January to April of 2019 and 2020.

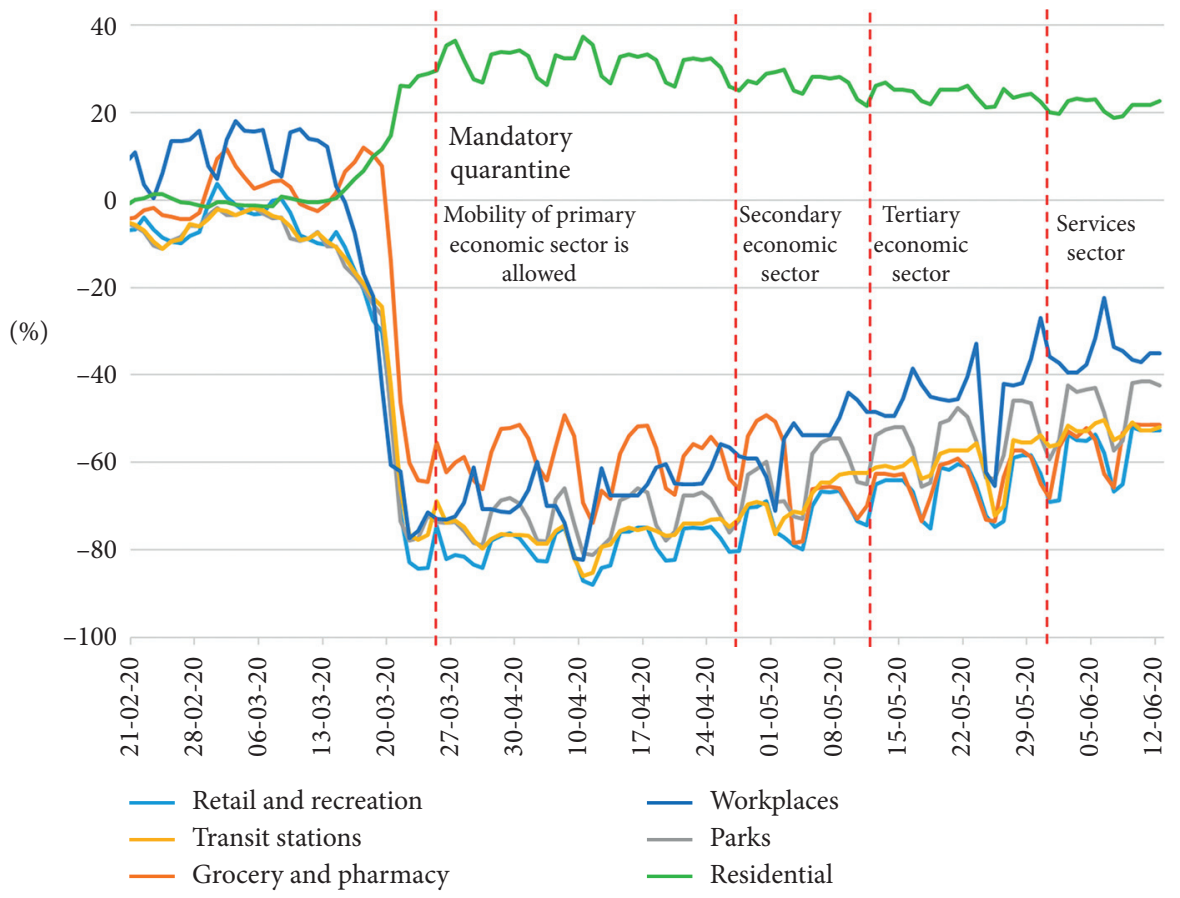

Figure 5: Activity times based on the mobility report for Colombia.

informal workers being public transport users who earn a living day to day and cannot stop working. Therefore, this situation highlights inequalities regarding the accessibility to opportunities of lower-income groups and the inadequate provision of transport systems.
We also performed a correlation analysis of the data to understand how the ability to carry out certain activities outside the home at certain times during the mandatory quarantine has influenced congestion levels and the use of public transport in cities. We decided to use spearman 


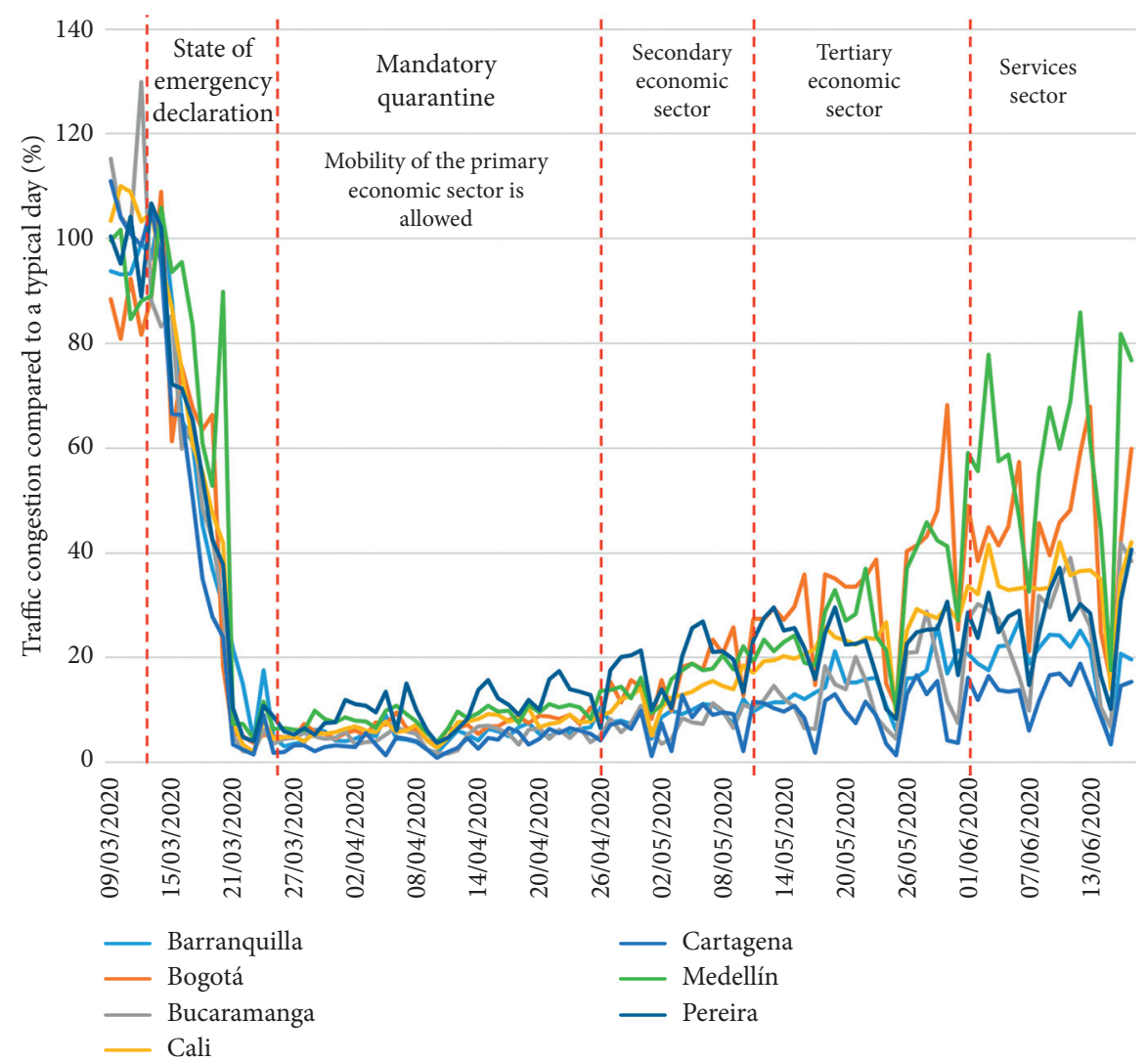

Figure 6: Traffic congestion changes in the seven Colombian cities during March and June.

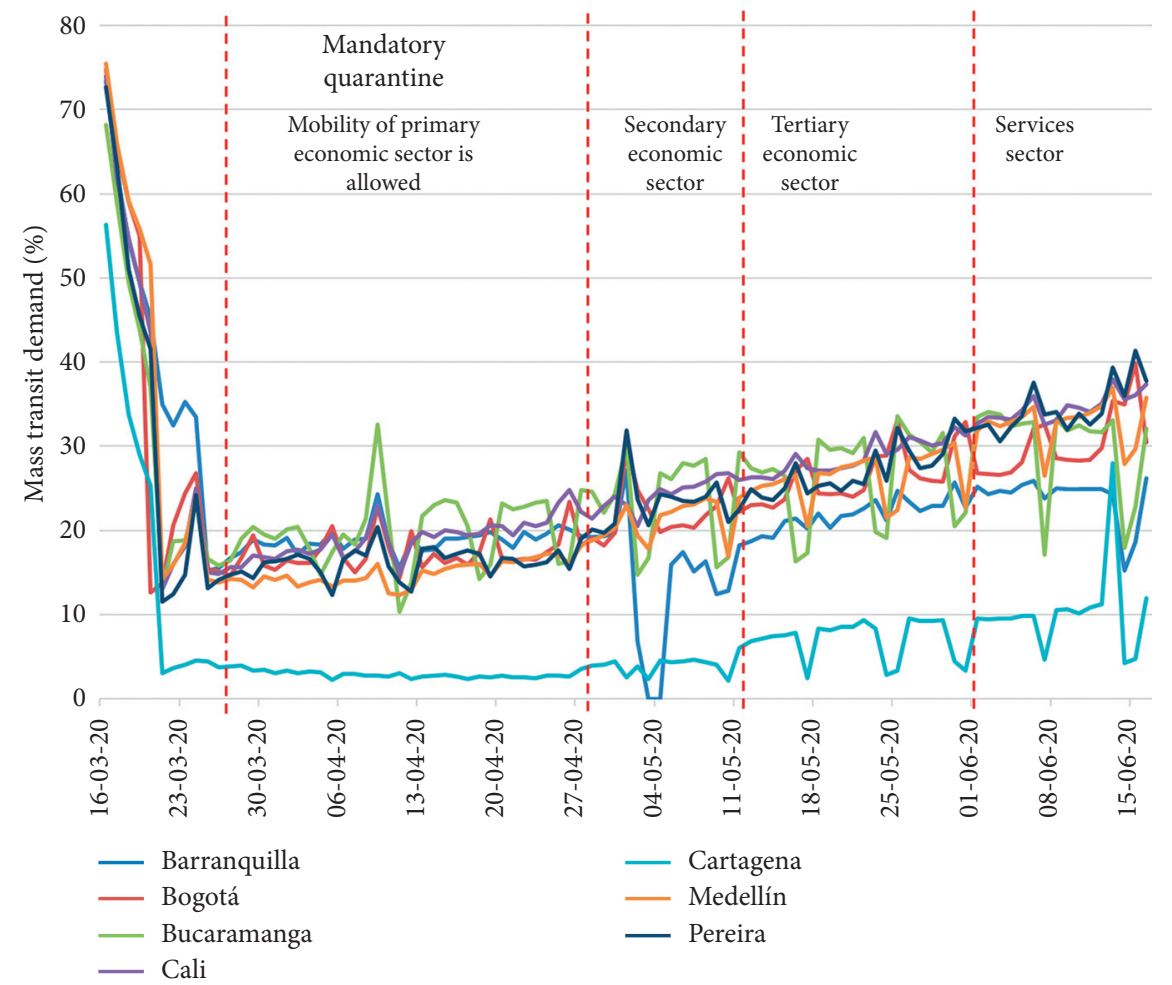

Figure 7: Public transport demand. 
correlations because the data do not follow normal distributions. Table 2 shows the correlations between changes in activity patterns compared to average changes in congestion levels and the use of public transport for Colombian cities. All correlations were significant at the $5 \%$ level. We found that retail and work have the strongest positive correlations with congestion levels and public transport use among all activities. As expected, residential time is negatively correlated with congestion levels and public transport use, which means that an increase in the time spent at home decreases congestion and public transport use. Public transport use was positively associated with congestion levels, suggesting that measures adopted by the government to allow certain activities influenced the number of trips on both public and private transport. Also, we found that the grocery and pharmacy activity has the lowest correlation with congestion levels and public transport use, maybe because people during the mandatory quarantine rely more than usual on online shopping or local stores in the vicinity of the households that can be reached by walking.

Due to the low expected demand for public transport in cities during the quarantine period, operators decided to decrease the transport supply. Despite running fewer buses, operators are in a difficult financial situation due to lower revenues from the low demand and the high fixed costs. Furthermore, all the systems are undertaking strict wash campaigns to sanitise the buses to avoid the outbreak of the virus and reduce the user perception of getting infected when using the system. The lower revenues during this virus crisis worsen the precarious economic situation that these systems have been experiencing, to the point that most operators have sent letters to encourage the government to adopt financial measures that allow them to survive and continue their operation without going to bankruptcy.

Considering that public transit operators of all cities decided to decrease their supply by running fewer buses and less frequently, we decided to analyse the hourly demand of a given system. Using data from Barranquilla's BRT system, Transmetro, we build Figure 8. The curves in this figure show that a working day during the mandatory quarantine has a similar demand trend that could be observed during a typical day (i.e., before the pandemic).

The morning peak during the mandatory quarantine is more pronounced than in a typical day. The above can impose an extra challenge if people have to wait longer due to lower public transport frequencies, which can generate a higher occupation and, in turn, create a dangerous situation that promotes the virus contagion. However, the demand out of that peak seems to be more distributed and flat compared to the typical situation. Also, operation ends earlier in the night (i.e., around 8:00 p.m.), which suggests that individuals are not travelling for discretionary purposes.

\section{Discussion}

In Colombia, urban trips, freight movements, and commercial flights diminished after the state of emergency declaration, the decision to close national borders, and social distancing measures. We found dramatic demand reductions (i.e., around $80 \%$ to $90 \%$ ) in all modalities after the mandatory quarantine adoption at the national level. The measures to reopen the economy have allowed for a slow increase in demand for urban transport systems, but it is still far below usual levels. Thus, social distancing and quarantine measures definitively caused a massive impact on activity and travel behaviour patterns.

Considering the results and the epidemiological expectations for the near future concerning the virus spread, we identified some hazards and threats to transport systems and extracted some lessons learned from the Colombian situation that can guide the preparedness of a country against possible upcoming public health crisis.

Regarding air transport, we identify that this public health crisis will have a negative financial effect that is a threat to air business sustainability. Specifically, the economic losses that are being suffered by stakeholders in the air transport business, especially airlines. In Colombia, Avianca Holdings, which is the leading airline in the country, faces a deep economic crisis. Although the company designed a new strategic plan, the COVID-19 pandemic is heightening its crisis. However, it is not a unique case. Other airlines, such as Viva Air, EasyFly, and LAN Colombia, also face a severe economic crisis. This is a massive challenge for the Colombian air transport sector, which will require financial support from the GoC in order to rescue this industry that is vital for the country.

In the case of freight transport, cargo volumes transported by trucks during the mandatory quarantine also exhibited a decrease, mainly explained by lower transport flows of nonessential goods. The manufacturing industry has been at a complete standstill resulting in reduced revenue. However, the extremely fragmented structure of supply in cargo vehicles, represented in smallholders, has allowed certain flexibility for adjusting to the new circumstances. In terms of our analysis, this sector has been the most resilient to the crisis caused by the COVID-19 pandemic. A highlight is that today freight transport operators are paying less for fuels and do not have to pay tolls. Furthermore, service provision is favoured by lower levels of congestion, which may have reduced its operational costs and externalities [41, 42].

Concerning urban transport, there are two complex challenges. The first has to do with financial crises due to the operational deficit during the mandatory quarantine. In Colombia, most public transit systems had already experienced financial difficulties before the COVID-19 pandemic. National subsidies to local public transport systems are prohibited by legislation, which only allows subsidising the operation with local resources [43]. However, local authorities have limited financial capacity, which worsens the current picture. The other challenge is to achieve demand returns at levels that were present before the COVID-19 pandemic. In the country, the majority of BRT systems operate with high occupancy densities, in some cases, with levels close to 8 passengers per square meter. These crowding levels facilitate the spread of the novel coronavirus if users do not use the appropriate protection equipment (e.g., protection mask), which could cause some users to migrate to other means of transport such as the motorcycle, in particular, for lower-income users. Then, although no 
TABLE 2: Correlation among activity, congestion, and public transport demand data.

\begin{tabular}{|c|c|c|c|c|c|}
\hline & Retail & Pharmacy & Workplaces & Residential & Congestion \\
\hline Congestion & $0.91^{* *}$ & $0.23^{*}$ & $0.90^{* *}$ & $-0.79^{* *}$ & 1.00 \\
\hline Public transport & $0.83^{* *}$ & $0.22^{*}$ & $0.79^{* *}$ & $-0.81^{* *}$ & $0.89^{* *}$ \\
\hline
\end{tabular}

${ }^{* *} p<0.01,{ }^{*} p<0.05$.

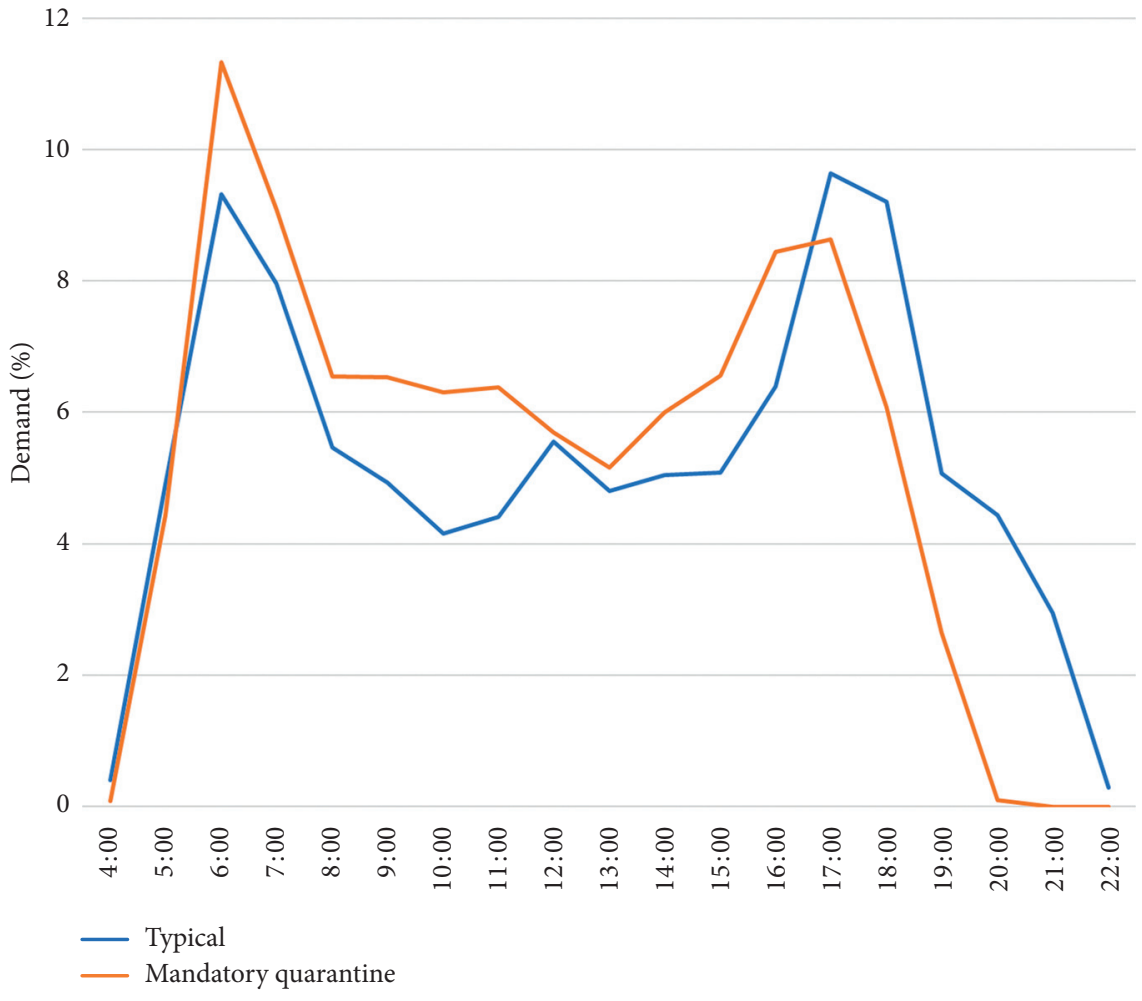

FIGURE 8: Hourly demand for Barranquilla's BRT system during typical and mandatory quarantine days.

conclusive studies confirm that the occupation of public transport systems is associated with higher contagion rates, local authorities should promote several measures to avoid contagion. Those measures include the use of protective elements for all passengers, recommendations to prevent close social contact while travelling (e.g., talking), the use of air conditioning in vehicles, and the continuous hand washing.

Public transport services should focus on reducing crowding levels at stations and buses. In the case of Bogotá where authorities promote bicycles as an alternative mode of transport, the potential of using the bicycle to relieve overcrowded public transport services for short-distance travel could be studied [44]. Policymakers can try to stimulate walking and cycling by allocating less-used street space to cyclists and pedestrians, especially in neighbourhoods that have no adequate walking and cycling infrastructure [45-47]. A strategy to avoid crowdedness in public transport service could be to maintain the regular supply by not diminishing the frequencies and the fleet of buses operating during the crisis. Given that this strategy has substantial financial barriers for the low revenues received by public transport operators, governments need to provide subsidies to maintain the system supply with an adequate level of service.
A second strategy for public transport operators during the crisis should be to have a heavy focus on hygiene and sanitation in order to avoid infections among passengers and maintain standards that would also promote positive user perception. The above generates the challenge of hiring additional staff to check the temperatures of their transport staff and, eventually, of the users daily, by implementing health control checkpoints. Activities of sanitising the bus fleet after each trip can take added time that will make the task of reducing overcrowding more difficult because of less bus availability. It may also be necessary to increase natural ventilation by retrofitting window vents.

Another way to mitigate the risk of picking up an infection on the public transport system is travelling at off-peak times. Authorities could promote off-peak shuttle fares aimed at attracting passengers to midmorning and mid-afternoon, especially for those users who have some flexibility of the schedule. Passengers could be financially rewarded for commuting off-peak $[48,49]$, and it could also be implemented using system information technologies to inform about crowding levels via a mobile phone application to change passengers' behaviour. Furthermore, companies could play a role by implementing company bus services, promoting 
sustainable travel behaviours, and considering the implementation of teleworking and flexitime [39].

\section{Conclusions}

This paper describes some of the impacts on three components of the transport system (i.e., air transport, freight transport, and urban transport) caused by the different policies adopted by the Colombian government to contain the COVID-19 spread. The analysis considers seven urban areas within the country and shows the reductions in demand, in all of its studied components.

Correlation analysis between activities and mobility shows that retail and work have the strongest positive correlations with congestion levels and public transport use among all activities. Meanwhile, residential time is negatively correlated with congestion levels and public transport use. On the other hand, grocery and pharmacy activity has the lowest correlation with congestion levels and public transport use.

The data analysis shows that measures at the national and local levels have decreased the demand for motorised trips across the cities, diminishing congestion levels, reducing transit ridership, and having a reduction in transport externalities. The country banned air transport for passengers and only allowed air cargo for medical and necessary supplies. Also, public transport vehicles must operate at a maximum of $35 \%$ of their capacity. Such policies will have negative consequences for the economics of the transport industry, worsening the financial crisis of operators of public transport systems and airlines. During the first three months of the COVID-19, freight was the most resilient transport component.

Governments should provide subsidies to maintain the system supply to avoid crowdedness and promote active transport by allocating less-used street space to cyclists and pedestrians. In the short term, transportation service providers will face a financial crisis, deepened by the pandemic, which will require the government assistance for their recovery.

On the other hand, the reductions in congestion levels in the cities caused some positive side effects regarding externalities. Mainly, lower trips have generated less traffic safety issues in the cities. Also, because of fewer vehicles circulating, some cities have reported environmental benefits. Specifically, there have been reductions in noise and pollution caused by mobile sources. In line with the report from Oxford Analytica [50], we expect that carbon emissions will diminish because of prolonged disruptions to economic activity. The longer this crisis persists, the more profound the short-term carbon impact will be [51].

Further research should evaluate the impact of the mandatory quarantine measure on travel perceptions, time use, activity, and travel patterns at the individual level. Also, the modal shares and destination choice impacts in the cities during the crisis. Bogotá, for example, opened more than 100 kilometres of bike lanes during the COVID-19 crisis to promote its use. Also, the MUVO company, with the support and financing of some organisations (i.e., New
Urban Mobility Alliance and Despacio), delivered 400 electric bicycles as a loan for medical workers in this city. Examining the impact of these strategies is worthy of research.

\section{Data Availability}

The data used to support the findings of this study are available from the corresponding author upon request.

\section{Conflicts of Interest}

The authors declare no conflicts of interest.

\section{Authors' Contributions}

Julian Arellana was involved in conceptualisation, literature review, methodology, and data analysis and wrote the original draft, reviewed, and edited the draft. Luis Márquez and Victor Cantillo were involved in conceptualisation, methodology, and data analysis and wrote the original draft, reviewed, and edited.

\section{Acknowledgments}

The authors want to express their gratitude to the Colombian Ministry of Transport and to public transport operators who provided the data for the analysis. Special thanks are due to Transmetro S.A., Metro Cali S.A., Integra S.A., and TransCaribe S.A.

\section{References}

[1] WHO, WHO COVID-19 Dashboard, WHO, Geneva, Switzerland, 2020, https://who.sprinklr.com/.

[2] J. Tay, Y. F. Ng, J. Cutter, and L. James, "Influenza A (H1N12009) pandemic in Singapore-public health control measures implemented and lessons learnt," Annals Academy of Medicine Singapore, vol. 39, no. 4, pp. 313-324, 2010.

[3] M. U. G. Kraemer, C.-H. Yang, B. Gutierrez et al., "The effect of human mobility and control measures on the COVID-19 epidemic in China," Science, vol. 4218, Article ID eabb4218, 2020.

[4] Z. Wu and J. M. McGoogan, "Characteristics of and important lessons from the coronavirus disease 2019 (COVID19) outbreak in China: summary of a report of 72314 cases from the Chinese Center for Disease Control and Prevention," Journal of the American Medical Association, vol. 323, no. 13, pp. 1239-1242, 2020.

[5] K. Li, Y. Qin, J. Wu, and J. Yan, "Containing the virus or reviving the economy? Evidence from individual expectations during the COVID-19 epidemic," SSRN Electronic Journal, 2020.

[6] H. Tian, Y. Liu, Y. Li et al., "An investigation of transmission control measures during the first 50 days of the COVID-19 epidemic in China," Science, vol. 368, no. 6491, pp. 638-642, Article ID eabb6105, 2020.

[7] W. J. McKibbin and R. Fernando, "The global macroeconomic impacts of COVID-19: seven scenarios," SSRN Electronic Journal, 2020.

[8] R. Baldwin and B. W. di. Mauro, Economics in the Time of COVID-19, R. Baldwin and B. W. di Mauro, Eds., Centre for Economic Policy Research, London, UK, 2020. 
[9] M. A. Ruiz Estrada and A. Khan, "Globalization and pandemics: the case of COVID-19," SSRN Electronic Journal, 2020.

[10] G. Wang, Y. Zhang, J. Zhao, J. Zhang, and F. Jiang, "Mitigate the effects of home confinement on children during the COVID-19 outbreak," The Lancet, vol. 395, no. 10228, pp. 945-947, 2020.

[11] P. Bucsky, "Modal share changes due to COVID-19: the case of Budapest," Transportation Research Interdisciplinary Perspectives, Article ID 100141, 2020.

[12] M. de Haas, R. Faber, and M. Hamersma, "How COVID-19 and the Dutch 'intelligent lockdown' change activities, work and travel behaviour: evidence from longitudinal data in the Netherlands," Transportation Research Interdisciplinary Perspectives, vol. 6, Article ID 100150, 2020.

[13] A. Aloi, B. Alonso, J. Benavente et al., "Effects of the COVID19 lockdown on urban mobility: empirical evidence from the city of Santander (Spain)," Sustainability, vol. 12, no. 9, p. $3870,2020$.

[14] J. De Vos, "The effect of COVID-19 and subsequent social distancing on travel behavior," Transportation Research Interdisciplinary Perspectives, vol. 5, Article ID 100121, 2020.

[15] D. M. Bell, I. B. Weisfuse, M. Hernandez-Avila, C. Del Rio, X. Bustamante, and G. Rodier, "Pandemic influenza as 21st century urban public health crisis," Emerging Infectious Diseases, vol. 15, no. 12, pp. 1963-1969, 2009.

[16] D. Ivanov, "Predicting the impacts of epidemic outbreaks on global supply chains: a simulation-based analysis on the coronavirus outbreak (COVID-19/SARS-CoV-2) case," Transportation Research Part E: Logistics and Transportation Review, vol. 136, Article ID 101922, 2020.

[17] M. Chinazzi, J. T. Davis, M. Ajelli et al., "The effect of travel restrictions on the spread of the 2019 novel coronavirus (COVID-19) outbreak," Science, vol. 368, no. 6489, pp. 395-400, 2020.

[18] C. Musselwhite, E. Avineri, and Y. Susilo, "Editorial JTH 16 -The Coronavirus Disease COVID-19 and implications for transport and health," Journal of Transport \& Health, vol. 16, Article ID 100853, 2020.

[19] A. J. Rodríguez-Morales, K. MacGregor, S. Kanagarajah, D. Patel, and P. Schlagenhauf, "Going global - travel and the 2019 novel coronavirus," Travel Medicine and Infectious Disease, vol. 33, Article ID 101578, 2020.

[20] S. Lin, J. Huang, Z. He, and D. Zhan, "Which measures are effective in containing COVID-19? Empirical research based on prevention and control cases in China," MedRxiv, 2020.

[21] Z. Du, L. Wang, S. Cauchemez et al., "Risk for transportation of 2019 novel coronavirus disease from Wuhan to other cities in China," Emerging Infectious Diseases, vol. 26, no. 5, 2020.

[22] C. Sohrabi, Z. Alsafi, N. O’Neill et al., "World Health Organization declares global emergency: a review of the 2019 novel coronavirus (COVID-19)," International Journal of Surgery, vol. 76, pp. 71-76, 2020.

[23] Z. Allam and D. S. Jones, "On the coronavirus (COVID-19) outbreak and the smart city network: universal data sharing standards coupled with artificial intelligence (AI) to benefit urban health monitoring and management," Healthcare, vol. 8, no. 1, p. 46, 2020.

[24] Y. Qiu, X. Chen, and W. Shi, "Impacts of social and economic factors on the transmission of coronavirus disease 2019 (COVID-19) in China," Journal of Population Economics, vol. 33, pp. 1127-1172, 2020.
[25] J. Tsai and M. Wilson, "COVID-19: a potential public health problem for homeless populations," The Lancet Public Health, vol. 5, no. 4, pp. e186-e187, 2020.

[26] World Bank, Urban Population (\% of Total Population), Data World Development Indicators, Colombia, 2018, https://data. worldbank.org/indicator/SP.URB.TOTL.IN.ZS?locations=CO.

[27] DANE, Censo Nacional de Población y Vivienda 2018, https:// www.dane.gov.co/index.php/estadisticas-por-tema/demografiay-poblacion/censo-nacional-de-poblacion-y-vivenda-2018, 2019.

[28] Aerocivil, Bases de Datos, Aeronautical Statistics, http://www. aerocivil.gov.co/atencion/estadisticas-de-las-actividadesaeronauticas/bases-de-datos, 2020.

[29] Flightradar24, Flightradar24 Web Page, https://www. flightradar24.com/about, 2020.

[30] Ministerio de Transporte, Portal Logístico de Colombia, https://plc.mintransporte.gov.co/, 2020.

[31] O. L. Sarmiento, D. Higuera-Mendieta, M. A. WilchesMogollon et al., "Urban transformations and health: methods for TrUST - a natural experiment evaluating the impacts of a mass transit cable car in Bogotá, Colombia," Frontiers in Public Health, vol. 8, p. 64, 2020.

[32] Secretaría Distrital de Movilidad, Encuesta de Movilidad 2019, https://www.movilidadbogota.gov.co/web/encuesta_de_ movilidad_2019, 2019.

[33] Area Metropolitana del Valle de Aburrá, Encuesta OrigenDestino AMVA, https://www.metropol.gov.co/encuesta_ od2017_v2/index.html\#/, 2017.

[34] Inter-American Development Bank and IDB Invest, IDB and IDB Invest Coronavirus Impact Dashboard Methodological Note, https://iadb-comms.org/IDB-IDBInvest-coronavirusimpact-dashboard-methodological-note, 2020.

[35] Google, COVID-19 Community Mobility Reports, Google, Menlo Park, CA, USA, 2020, https://www.google.com/ covid19/mobility/.

[36] S. M. Iacus, F. Natale, C. Santamaria, S. Spyratos, and M. Vespe, "Estimating and projecting air passenger traffic during the COVID-19 coronavirus outbreak and its socioeconomic impact," Safety Science, vol. 129, Article ID 104791, 2020.

[37] Subsecretaría Técnica-Secretaría de Movilidad de Medellin, Respuesta institucional en transporte a la coyuntura COVID19 en Medellin y el Valle de Aburrá, 2020.

[38] V. Cantillo and J. de D. Ortúzar, "Restricting the use of cars by license plate numbers: a misguided urban transport policy," DYNA (Colombia), vol. 81, no. 188, pp. 75-82, 2014.

[39] L. A. Guzman, J. Arellana, and V. Alvarez, "Confronting congestion in urban areas: developing Sustainable Mobility Plans for public and private organizations in Bogotá," Transportation Research Part A: Policy and Practice, vol. 134, pp. 321-335, 2020.

[40] R. Ramos, V. Cantillo, J. Arellana, and I. Sarmiento, "From restricting the use of cars by license plate numbers to congestion charging: analysis for Medellin, Colombia," Transport Policy, vol. 60, 2017.

[41] L. Berrio, V. Cantillo, and J. Arellana, "Strategic modelling of passenger transport in waterways: the case of the magdalena river," Transport, vol. 34, no. 3, pp. 215-224, 2019.

[42] L. Márquez and V. Cantillo, "Evaluating strategic freight transport corridors including external costs," Transportation Planning and Technology, vol. 36, no. 6, pp. 529-546, 2013.

[43] D. Toro-González, V. Cantillo, and V. Cantillo-García, "Factors influencing demand for public transport in Colombia," Research in Transportation Business \& Management, Article ID 100514, 2020. 
[44] L. Márquez, J. V. Alfonso, and J. C. Poveda, "In-vehicle crowding: Integrating tangible attributes, attitudes, and perceptions in a choice context between BRT and metro," Transportation Research Part A: Policy and Practice, vol. 130, pp. 452-465, 2019.

[45] J. Arellana, M. Saltarín, A. M. Larrañaga, V. Alvarez, and C. A. Henao, "Urban walkability considering pedestrians' perceptions of the built environment: a 10-year review and a case study in a medium-sized city in Latin America," Transport Reviews, vol. 40, no. 2, pp. 183-203, 2020.

[46] M. Gutiérrez, V. Cantillo, J. Arellana, and J. de Dios Ortúzar, "Estimating bicycle demand in an aggressive environment," International Journal of Sustainable Transportation, pp. 1-14, 2020.

[47] J. Arellana, M. Saltarín, A. M. Larrañaga, V. I. González, and C. A. Henao, "Developing an urban bikeability index for different types of cyclists as a tool to prioritise bicycle infrastructure investments," Transportation Research Part A: Policy and Practice, vol. 139, pp. 310-334, 2020.

[48] J. Arellana, A. Daly, S. Hess, J. de D. Ortúzar, and L. Rizzi, "Development of surveys for study of departure time choice," Transportation Research Record: Journal of the Transportation Research Board, vol. 2303, pp. 9-18, 2012.

[49] M. Thorhauge, J. Rich, and E. Cherchi, Departure Time Choice: Modelling Individual Preferences, Intention and Constraints, Technical University of Denmark, Lyngby, Denmark, 2015, http://orbit.dtu.dk/fedora/objects/orbit: 142602/datastreams/file_116811052/content.

[50] Oxford Analytica, "COVID-19 global climate impact may be brief," in Emerald Expert Briefings, Oxford Analytica, Oxford, UK, 2020.

[51] M. A. Ruiz Estrada, D. Park, and M. Lee, "The evaluation of the final impact of Wuhan COVID-19 on trade, tourism, transport, and electricity consumption of China," SSRN Electronic Journal, 2020. 